\title{
Papillary Thyroid Carcinoma within Thyroglossal Duct Cyst: Case Series and Literature Review
}

\author{
Haissan Iftikhar ${ }^{1} \quad$ Mubasher Ikram $^{1} \quad$ Karim Rizwan Nathani $^{2} \quad$ Adnan Yar Muhammad $^{1}$ \\ ${ }^{1}$ Department of Surgery, Aga Khan University Hospital, Karachi, \\ Sindh, Pakistan \\ 2 Medical College, Aga Khan University, Karachi, Sindh, Pakistan \\ Address for correspondence Haissan Iftikhar, MBBS, Department of \\ Surgery, Aga Khan University Hospital, Main Stadium Road Karachi, \\ Karachi, Sindh 74800, Pakistan (e-mail: haissaniftikhar@gmail.com).
}

Int Arch Otorhinolaryngol 2018;22:253-255.

\begin{abstract}
Introduction Thyroglossal duct cyst (TGDC) is the most common congenital anomaly of the neck, and approximately $7 \%$ of all the adult population presents it. Ectopic thyroid tissue is found in the thyroglossal duct cyst wall in up to $65 \%$ of cases. This thyroid tissue has the potential to develop some type of malignancy, the most common of which is the papillary carcinoma of the thyroid. There are just over 270 cases of thyroglossal duct cyst malignancy reported in the literature.

Objectives We aimed to study our population of patients in order to identify cases with thyroglossal duct cyst malignancy.

Methods A retrospective chart review was conducted in the section of otolaryngology/head and neck surgery at a hospital in Karachi, Pakistan, from January of 2004 to December of 2014 on patients with the diagnosis of thyroglossal duct cyst.

Results Fifty-eight patients were diagnosed with TCDC, two of whom also presented with thyroglossal duct cyst carcinoma. Both patients revealed papillary thyroid

Keywords

- carcinoma, papillary

- cysts

- thyroglossal cyst

- neck carcinoma on histopathology. Case 1 had an open biopsy before undergoing definitive surgery. Both patients underwent subsequent total thyroidectomy after Sistrunk procedure, and case 2 had selective neck dissection revealing lymph node metastasis. Conclusion Thyroglossal duct cyst carcinoma is a rare finding that comes as a surprise to both the patient and the surgeon. We report 2 out of 58 cases diagnosed with thyroglossal duct cyst carcinoma.
\end{abstract}

\section{Introduction}

The thyroid gland arises from the foramen cecum and descends in the neck to its final resting place in the pretracheal space. An anomaly in this descent might leave space in the tract, which leads to the formation of the thyroglossal duct cyst (TGDC). It is estimated that around $7 \%$ of the adult population have a persistent duct, therefore, leading to the formation of TGDC. This cyst is lined by squamous or pseudo stratified ciliated columnar epithelium. The cyst might also contain some remnants of ectopic thyroid gland, which is normally found in the cyst wall.

received

May 19, 2017

accepted

July 16,2017

published online

October 25, 2017
The TGDC tends to get infected and lead to swelling and discomfort in the anterior neck. In the cases left untreated, recurrent infections can lead to sinus or fistula formation. The definitive treatment for TGDC is surgery. Sistrunk operation is performed to remove the TGDC and its tract. $^{1}$

In very rare instances, the histopathology of the specimen reveals thyroid cancer, particularly papillary thyroid carcinoma. There have been around 278 reported cases of malignancy associated with TGDCs. We report two such cases of papillary thyroid carcinoma arising from a TGDC.

Copyright (e 2018 by Thieme Revinter Publicações Ltda, Rio de Janeiro, Brazil 


\section{Materials and Methods}

A retrospective chart review was conducted at a tertiary care hospital from January of 2004 to December of 2014. A total of 58 cases were identified with the diagnosis TGDC that were subjected to Sistrunk operation. Out of the 58 cases, 2 were identified that revealed papillary thyroid carcinoma on final histopathology of a sample from the cyst. These cases were individually studied and are reported in this study along with a review of the literature. Patients demographics, such as age, gender and comorbidities, site of TGDC, type of carcinoma, type of surgery, postoperative radio-iodine ablation and follow-up were noted.

\section{Results}

\section{Case 1}

A 38-year-old gentleman with no comorbidity presented with anterior neck swelling for the past 5 years. Ultrasound examination of the neck revealed TGDC. The patient had undergone excisional biopsy of the lesion at a tertiary care center, the result of which showed papillary thyroid carcinoma; he, then, underwent formal Sistrunk procedure along with total thyroidectomy without neck dissection. The final histopathology showed no malignancy in the residual TGDC and, furthermore, no malignancy in the thyroid gland. The patient has been on regular follow-up for the past 36 months and has remained disease-free.

\section{Case 2}

A 45-year-old gentleman with a known case of hypertension presented with swelling in the anterior neck that had been progressively increasing in size for the past 5 months. Ultrasound of the neck revealed TGDC. The patient underwent Sistrunk procedure, and the final histopathology revealed papillary thyroid carcinoma along with normal cyst wall. The patient further underwent total thyroidectomy and bilateral selective neck dissection. The final histopathology revealed benign thyroid tissue; however, level III of left revealed 2 nodes involved by the tumor. The patient subsequently underwent radio-iodine ablation with $100 \mathrm{mcg}$. The patient has been on follow-up for the past 6 years and has remained disease-free. Refer to - Table 1 and - Table 2.

\section{Discussion}

Thyroglossal duct cyst is the most common midline congenital anomaly of the neck. It accounts for $70 \%$ of all congenital neck masses. ${ }^{2}$ The TGDC has some normal thyroid tissue in $5-67 \%$ of all cases. ${ }^{3}$ This thyroid tissue is normally located in the wall of the cyst and has a potential to harbor malignancy. ${ }^{3}$ The first case of carcinoma within the cyst was reported by Brentano in 1911., ${ }^{4,5}$ The most common type of malignancy observed arising from within the cyst is the papillary thyroid carcinoma. ${ }^{3}$ Due to the rarity of such occurrence, this finding comes as a surprise to both the patient and physician alike. ${ }^{4}$

The incidence of malignancy in the TGDC varies from study to study, and this large variation is due to the small number of reported cases coupled with the total number of cases studied of TGDC, which is required to calculate the incidence. ${ }^{4}$ The incidence, however, is thought to be around $1.6 \%$, as seen by in two large series. ${ }^{6,7}$ In our case, we have 2 out of 58 cases under investigation showing papillary carcinoma, which gives us an incidence of $3.4 \%$.

The definitive treatment for the TGDC is the removal of the cyst along with some part of the hyoid (body) and excision of the duct tract. Schlange, in 1893, first described the surgical procedure as excision of the cyst and a part of the hyoid bone. ${ }^{8}$ This procedure had a high recurrence rate. Walter Ellis Sistrunk, in 1920, described a slightly more extensive procedure, which included cystectomy central

Table 1 Patient demographics and presentation

\begin{tabular}{|l|l|l|l|l|l|l|l|}
\hline & $\begin{array}{l}\text { Age } \\
\text { (year) }\end{array}$ & Gender & Comorbidity & $\begin{array}{l}\text { Duration of symptoms } \\
\text { (months) }\end{array}$ & $\begin{array}{l}\text { Presenting symptoms } \\
\text { (neck swelling) }\end{array}$ & FNAC & Site of TGDC \\
\hline Case 1 & 38 & Male & None & 60 & Yes & No & Infrahyoid \\
\hline Case 2 & 45 & Male & HTN & 5 & Yes & No & Infrahyoid \\
\hline
\end{tabular}

Abbreviations: FNAC, fine needle aspiration cytology; HTN, hypertension; TGDC, thyroglossal duct cyst.

Table 2 Treatment and follow-up

\begin{tabular}{|l|l|l|l|l|l|l|l|}
\hline & Type of surgery & $\begin{array}{l}\text { Final } \\
\text { histopathology }\end{array}$ & $\begin{array}{l}\text { Total } \\
\text { Thyroidectomy }\end{array}$ & $\begin{array}{l}\text { Lymph node } \\
\text { metastasis }\end{array}$ & $\begin{array}{l}\text { Radio-iodine } \\
\text { ablation }\end{array}$ & $\begin{array}{l}\text { Follow-up } \\
\text { (Months) }\end{array}$ & $\begin{array}{l}\text { Status at last } \\
\text { follow-up }\end{array}$ \\
\hline Case 1 & Sistrunk procedure & PTC & Yes & NA & No & 36 & $\begin{array}{l}\text { Alive, } \\
\text { disease-free }\end{array}$ \\
\hline Case 2 & Sistrunk procedure & PTC & Yes & Yes & Yes & 72 & $\begin{array}{l}\text { Alive, } \\
\text { disease-free }\end{array}$ \\
\hline
\end{tabular}

Abbreviation: PTC, Papillary thyroid carcinoma. 
hyoidectomy (removal of body of hyoid) and tract excision up to the base of the tongue. ${ }^{1,8}$ This had lower recurrence rate when compared with the first procedure and is considered a gold standard for the treatment of TGDC to date.

Preoperative fine needle aspiration cytology (FNAC) is required to rule out malignancy, which cannot be established until further evidence. S.Wei et al investigated 217 patients with TGDC. Thirty-nine of the patients underwent FNAC, 37 (94.9\%) of whom showed macrophages and 2 who showed ectopic thyroid tissue. ${ }^{3}$ The thyroid tissue is embedded within the fibrotic cyst wall, which is not easily accessed, therefore, making FNAC an unreliable tool to diagnose a malignancy from the TGDC. ${ }^{3}$ None of the patients in this study underwent FNAC.

The pyramidal lobe is found in nearly half of the thyroid gland and can have attachment with the hyoid bone via a fibrotic band. ${ }^{3}$ The incidence of an isolated focus of papillary thyroid cancer in the pyramidal lobe is very low, approximately $0.4 \%{ }^{9}$ Metastasis of papillary carcinoma to lymph nodes tend to form cysts. ${ }^{3,10}$ The pyramidal lobe of thyroid and the Delphian node are both found in the midline; therefore, it is important to differentiate papillary thyroid carcinoma arising from the duct cyst from the other two. ${ }^{3}$ Given the two conditions, papillary thyroid carcinoma arising from the pyramidal lobe or from the Delphian node cyst can be confused with TGDC carcinoma if not examined carefully. ${ }^{3}$ In our study, in both of these patients normal thyroid tissue along with thyroglossal duct remnants were identified.

Due to the indolent course of papillary thyroid carcinoma and its ability to arise from ectopic thyroid tissue independent of the thyroid gland, a formal Sistrunk procedure without total thyroidectomy can suffice in the low-risk group. ${ }^{4}$ For clinically suspicious cases, radiological examination and FNAC of the thyroid nodule can suggest further treatment. ${ }^{4}$ In our study, both patients underwent total thyroidectomy, with case 2 also undergoing bilateral selective neck dissection due to suspicious nodes on radiological examination. On histopathology, neither patient had evidence of malignancy in the thyroid gland, but case 2 had two nodes positive for tumor metastasis to left level III. Cervical nodal metastasis has been reported from $10-15 \%$ in such cases; ${ }^{4}$ however, in our study it represented $50 \%$ (case 2 ) of our sample, but that cannot be generalized based on two cases.
Extensive investigation for a disease that can be diagnosed clinically is not warranted, especially given the low incidence of malignancy associated TGDC, but high-risk patients aged $>45$ years with clinical suspicion can be referred to FNAC and ultrasound of neck.

\section{Conclusion}

We report 2 cases of papillary thyroid carcinoma arising from a TGDC from 58 cases under review. Both patients underwent Sistrunk operation and total thyroidectomy. Both patients are stable and disease-free since the time of surgery up until the last follow-up. We suggest further investigation and thyroidectomy with or without neck dissection in the high-risk group.

\section{References}

1 Sistrunk WE. The surgical treatment of cysts of the thyroglossal tract. Ann Surg 1920;71(02):121, 2

2 Shahin A, Burroughs FH, Kirby JP, Ali SZ. Thyroglossal duct cyst: a cytopathologic study of 26 cases. Diagn Cytopathol 2005;33(06): 365-369

3 Wei S, LiVolsi VA, Baloch ZW. Pathology of thyroglossal duct: an institutional experience. Endocr Pathol 2015;26(01):75-79

4 Patel SG, Escrig M, Shaha AR, Singh B, Shah JP. Management of well-differentiated thyroid carcinoma presenting within a thyroglossal duct cyst. J Surg Oncol 2002;79(03):134-139, discussion 140-141

5 Brentano H. Struma aberrata lingual mit druzen metastasen. Dtsch Med Wochenschr 1911;37:665

6 LiVolsi VA, Perzin KH, Savetsky L. Carcinoma arising in median ectopic thyroid (including thyroglossal duct tissue). Cancer 1974; 34(04):1303-1315

7 Heshmati HM, et al. Thyroglossal duct carcinoma: report of 12 cases. Mayo Clin Proceed 1997;72(04):315-319

8 Zaman SU, Ikram M, Awan MS, Hassan NH. A Decade of Experience of Management of Thyroglossal Duct Cyst in a Tertiary Care Hospital: Differentiation Between Children and Adults. Indian J Otolaryngol Head Neck Surg 2017;69(01):97-101

9 Santrac N, Besic N, Buta M, et al. Lymphatic drainage, regional metastases and surgical management of papillary thyroid carcinoma arising in pyramidal lobe-a single institution experience. Endocr J 2014;61(01):55-59

10 Sternberg SS, Mills SE, Carter D. Sternberg's diagnostic surgical pathology. Vol. 1. 2004: Lippincott Williams \& Wilkins 